\title{
RESIDUAL GRAVITY ANALYSIS OF SELECTED CROSS SECTIONS \\ OF THE HANFORD RESERVATION
}

by

\author{
Benjamin H. Richard \\ Consultant
}

\author{
to \\ Ground Water Management Section \\ Research Department \\ Atlantic Richfield Hanford Company \\ Richland, Washington 99352 \\ Under Contract Number $\mathrm{CA}-200$
}

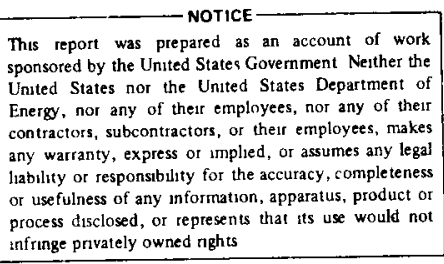

July 1976

Prepared for Atlantic Richfield Hanford Company,

A Prime Contractor to the U. S. Energy Research and Development Administration, Under Contract Number E (45-1)-2130 


\section{DISCLAIMER}

This report was prepared as an account of work sponsored by an agency of the United States Government. Neither the United States Government nor any agency Thereof, nor any of their employees, makes any warranty, express or implied, or assumes any legal liability or responsibility for the accuracy, completeness, or usefulness of any information, apparatus, product, or process disclosed, or represents that its use would not infringe privately owned rights. Reference herein to any specific commercial product, process, or service by trade name, trademark, manufacturer, or otherwise does not necessarily constitute or imply its endorsement, recommendation, or favoring by the United States Government or any agency thereof. The views and opinions of authors expressed herein do not necessarily state or reflect those of the United States Government or any agency thereof. 


\section{DISCLAIMER}

Portions of this document may be illegible in electronic image products. Images are produced from the best available original document. 
$\mathrm{N} O \mathrm{~T} I \mathrm{I} \quad \mathrm{E}$

This report was prepared as an account of work sponsored by the United States Government. Neither the United States, nor the United States Energy Research and Development Administration, nor any of their employees, nor any of their contractors, subcontractors, or their employees, makes any warranty, express or implied, or assumes any legal liability or responsibility for the accuracy, completeness, or usefulness of any information, apparatus, product or process disclosed, or represents that its use would not infringe privately owned rights. 
TABLE OF CONTENTS

Page

ACKNOWLEDGMENTS

iv

ABSTRACT

iv

INT RODUCT ION

1

PURPOSE AND SCOPE

1

PREVIOUS WORK

1

GRAVITY STUDY

1

INTRODUCTORY COMMENTS

1

FIELD PROCEDURES

3

$\begin{array}{ll}\text { DATA CORRECTIONS } & 4\end{array}$

ERROR ANALYSIS AND LIMITATIONS 25

RESULTS

GABLE MOUNTAIN PROFILE

GABLE BUTTE PROFILE

NORTH-SOUTH GABLE MOUNTAIN-GABLE BUTTE PROFILE

YAKIMA BARRICADE PROFILE

300 AREA PROFILE

TWO-DIMENSIONAL GRAVITY MODEL RESULTS

CONCLUSIONS

REFERENCES

DISTRIBUTION

APPENDIX 
FIGURE 1 LOCATION OF GRAVITY PROFILES

$A-B=$ GABLE MOUNTAIN

$C-D=$ GABLE BUTTE

$\mathrm{E}-\mathrm{F}=$ NORTH-SOUTH GABLE MOUNTAIN-GABLE BUTTE

$\mathrm{G}-\mathrm{H}=$ YAKIMA BARRICADE

$I-J=300$ AREA

FIGURE 2 TWO-DIMENSIONAL GRAVITY MODELS OF THE PROFILES

9 SHOWN ON FIGURE I $A-B=$ GABLE MOUNTAIN

$C-D=$ GABLE BUTTE

$E-F=$ NORTH-SOUTH GABLE MOUNTAIN-GABLE BUTTE

$\mathrm{G}-\mathrm{H}=$ YAKIMA BARRICADE

$I-J=300$ AREA

FIGURE 3 LOCATION OF POSSIBLE BURIED RIVER CHANNELS SUGGESTED BY THE GRAVITY PROEILES SHOWN IN FIGURE 1 AND THE RESIDUAL GRAVITY MAP OF THE HANFORD RESERVATION

PLATE 1 RESIDUAL GRAVITY PROFILES OF SELECTED SITES ON THE HANFORD RESERVATION

Pocket

\section{LIST OF TABLES}

TABIE 1 GABLE MOUNTAIN GRAVITY PROFILE DATA

TABLE 2 GABLE BUTTE GRAVITY PROFILE DATA

TABLE 3 NORTH-SOUTH GABLE MOUNTAIN-GABLE BUTTE

TABLE GRAVITY PROFILE DATA 


\section{ACKNOWLEDGMENTS}

The author would like to acknowledge the help of Messrs. R. E. Gephart, R. A. Deju, R. E. Isaacson, and D. J. Brown of Atlantic Richfield Hanford Company, and Mr. J. T. Lillie of Wright State University.

ABSTRACT

Gravity data were collected along selected sites on the Hanford reservation. Residual gravity profiles were calculated. These data were then modeled using the Talwani two-dimensional gravity model. Analysis of these models suggests the location of several buried stream channels. The northern channel is believed to represent the ancestral Columbia when it flowed through a synclinal trough between Gable Mountain and Gable Butte, and the southern channel is believed to reflect a previous location of the Yakima River. 


\section{INTRODUCTION}

\section{PURPOSE AND SCOPE}

This study expands the work previously reported by Deju and Richard ${ }^{1}$ along selected profiles on the Hanford reservation. Gravity data were gathered along these profiles with a 200- to 1,000-foot station spacing. These data were gathered during the summer of 1975 and were subsequently analyzed. The resultant residual gravity profiles are examined to determine:

1. The locations of potential buried stream channels;

2. The character of the bedrock surface;

3. The value of detailed gravity profiles to improve the knowledge of the bedrock surface.

Error analysis and field verification of the results were conducted to assure credibility of the conclusions.

\section{PREVIOUS WORK}

The original Bouguer gravity study of the area was conducted by Peterson. ${ }^{2,3}$ Deju and Richard ${ }^{1}$ further refined the above data by removing the topographic and regional gravity effects. All these studies have an average station density of less than one station per square mile and totally lack data in some key areas.

The previous work established areas where there could be a buried stream channel or where there were lows in the basalt bedrock surface. Because of the sparsity of data, additional gravity studies were needed to refine the definition of these anomalies.

\section{GRAVITY STUDY}

\section{INTRODUCTORY COMMENTS}

Five different sites were defined for detailed residual gravity profiles (Figure 1). These were:

1. Gable Mountain Profile (Figure 1, Profile A-B);

2. Gable Butte Profile (Figure 1, Profile C-D);

3. North-South Gable Mountain-Gable Butte Profile (Figure 1, Profile E-F); 
BHR-1

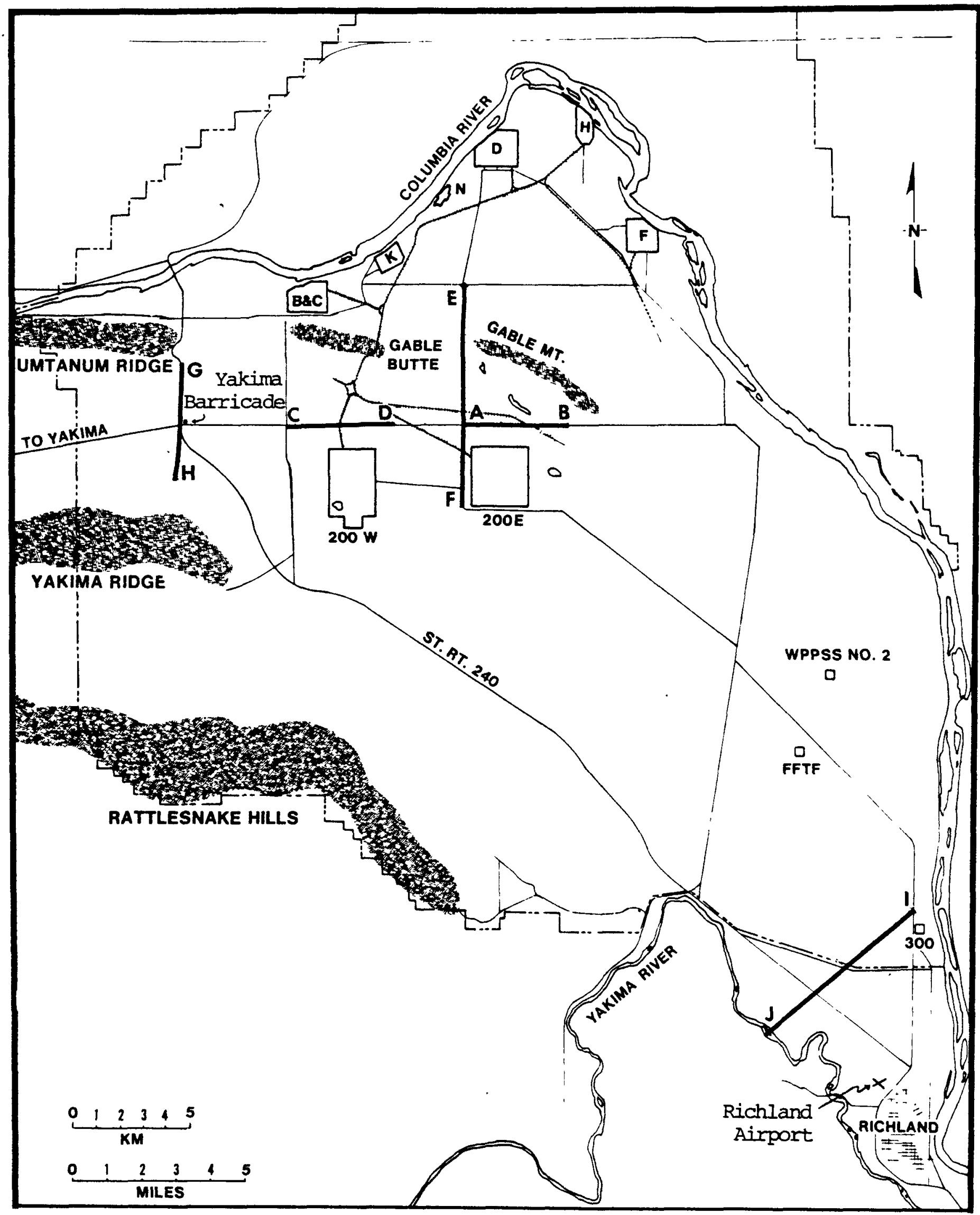

FIGURE 1 
4. Yakima Barricade Profile (Figure 1, Profile G-H); and,

5. 300 Area Profile (Figure 1, Profile I-J).

Profiles 1, 2, and 3 were selected because the original study by

Deju and Richard ${ }^{l}$ indicated possible buried stream channels and a bedrock high to the south of Gable Mountain and Gable Butte. The station spacing was selected to assure enough detail to identify any buried bedrock channels that may be present. Profile 4 was selected to add detail to a major basalt bedrock low shown in the former study. Because this was a large low, altimeter elevation control and a coarser station density gave adequate results. The site of Profile 5 is the location of a possible outlet of one of the buried stream channels from the Pasco Basin. As this would be a major channel, a coarse station density and altimeter elevation control were also adequate to delineate the channel.

The first two profiles had a 200-foot station spacing and an elevation accuracy of \pm .01 foot. The third profile had a 300-foot station spacing with the same elevation control. Profiles 4 and 5 were reconnaissance profiles. Profile 4 had a station spacing of about 500 feet, and Profile 5 had a station spacing of about 1,000 feet. Elevations for these stations were determined to an accuracy of \pm 3 feet with a Paulin Altimeter. A total of 348 stations were investigated to determine gravity variations along these profiles.

\section{FIELD PROCEDURES}

The stations of Profiles 1 through 3 were taped with a 100-foot tape and surveyed with a zeis $\mathrm{Ni}-1$ level to an elevation accuracy of \pm .01 foot. The stations of Profile 4 were also located with a tape, but the elevations were established with a Paulin Altimeter. The altimeter survey was conducted in early morning on meteorologically quiet days. The surveys were completed before there was a temperature inversion. This provided the most stable altimeter operation. Drift curves for the altimeter were constructed from multiple base station readings. These curves were then compared with the drift of the barometer of the Battelle-Northwest Meteorological Station for consistency. Except for possible individual station errors, this survey yielded an elevation accuracy of \pm 3 feet. The station spacing of profile 5 was located with distances measured with a field vehicle odometer and then further located using roads, section lines, and other political features. 
The elevations were also determined using an altimeter, but, in this case, after the temperature inversion. The drift curve was constructed in the same way as Profile 4 and again compared to the Battelle-Northwest Meteorological station barometer. This profile has the same accuracy as profile 4. It should be noted, however, that wind gusts did exist during the recording of Stations 25 through 35 and these gusts could have caused some errors in the elevation readings.

All gravity data were gathered with a Lacoste and Romberg gravity meter that has a reading precision of \pm .01 milligal. Station $0-1$ of the Gable Mountain Profile was used as the prime base station. This station was tied into the Richland Airport base station of Peterson ${ }^{3}$ with three loops to assure a correct tie. This tie gives station 0-1 an observed gravity value of 980.68962 centimeters per square second. The first station of each profile was established as a secondary base station and tied into station 0-1 of the Gable Mountain Profile with three loops to assure a correct tie. Tidal variation and instrument drift were removed from the readings by returning to the base station every two hours and plotting a drift curve from these readings.

\section{DATA CORRECTIONS}

The following field data corrections were made to examine the relative gravity anomalies caused by shallow density variations.

1. Corrections that move all field data to a common datum (450-foot elevation in this report):

a. Free air correction ( 0.09406 milligal per foot)--this correction added if the datum is below the elevation of the field point;

b. Bouguer correction ( $0.0127 \mathrm{x}$ density per foot)--this correction is subtracted if the datum is below the elevation of the field station; a density of unsaturated glaciofluviatile materials $(1.7$ grams per cubic centimeter) was used for this reduction.

2. Corrections that remove variations caused by differences in the time of the reading and the horizontal location of the station:

a. Drift and tidal effects--this correction is determined by reading a base station value every two hours, plotting this variation as a function of time, and removing this time variation from all station values; 
b. Horizontal location corrections--this correction is a latitude correction; gravity increases to the north and decreases to the south. The magnitude of this change is 1.307 sin $2 \theta$ milligals per mile, where $\theta$ is the latitude. If the station is south of the base station, this value must be added; if north, subtracted.

3. Corrections for irregular terrain--this correction adds the values to the field data that eliminate errors in the Bouguer anomaly caused by valleys and hills adjacent to the field station. This requires the use of an overlay on a topographic map, the establishment of an average elevation for each of many sectors in the overlay, multiplying these elevations by constants, adding all these numbers together and multiplying the resultant number by a constant that is a ratio of the density of the basalt (2.86 grams per cubic centimeter) to 2.0 grams per cubic centimeter (this ratio is 1.43). Dobrin ${ }^{4}$ describes this method in detail. Where these corrections were made in this report, they were taken from a map produced this way by Deju and Richara. ${ }^{1}$

4. Removal of deep-seated variations--this is more qualitative than all other corrections and is thus subject to a larger error. This study removed the regional variation from all profiles, except the one at the Yakima Barricade, by using a third order polynomial surface constructed from data points exclusive of data over known areas of thick cover over the basalt surface. The polynomial data are subtracted from the terrain-corrected data to produce residual surfaces representative of the shallow density variations. The Yakima Barricade Profile was too close to the edge of the map for the residual surface to be valid. For this reason, the deep-seated effects were assumed to vary uniformly from one end of the profile to the other.

\section{ERROR ANALYSIS AND LIMITATIONS}

Quantitative evaluation of the profiles is difficult because accurate average density measurements of glaciofluviatile material and the Ringold Formation are not available. The Talwani, et al., 5 two-dimensional gravity model was used to calculate the geologic profiles of the gravity rrofiles. The controls for these models are as follows: 
1. Gravity data--error in data is shown by error flags on Plate 1;

2. Well logs--all wells that reached bedrock depth were used in the original bedrock profile;

3. A density contrast of .65 grams per cubic centimeter between watersaturated glaciofluviatile and Ringold Formation materials to the basalt.

There is no way to determine:

1. The percent error in density;

2. Precise depths to the basalt surface along the gravity profiles;

3. The amount the profiles deviate from the assumptions for the twodimensional model.

For these reasons, the following results must be considered qualitative.

\section{RESULTS}

\section{GABLE MOUNTAIN PROFILE}

Table 1 in the Appendix lists the relative Bouguer and residual gravity anomalies for the stations of the Gable Mountain Profile (see Figure 1 for profile location). Comparison of the residual anomaly of this profile to the residual gravity map of the Hanford reservation ${ }^{1}$ shows general agreement. This profile cuts across an anticlinal structure in the basalt. The residual anomaly shows steps (see plate 1). These steps are believed to be caused by buried basalt cliffs.

\section{GABLE BUTTE PROFILE}

Table 2 in the Appendix lists the relative Bouguer and residual gravity anomalies for the stations of the Gable Butte Profile (see Figure 1 for profile location). Comparison of this profile to the residual gravity map of the Hanford reservation ${ }^{1}$ shows general agreement, as did the Gable Mountain Profile. The residual anomaly also cuts across the same bedrock high (see Plate 1).

NORTH-SOUTH GABLE MOUNTAIN-GABLE BUTTE PROFILE

Table 3 in the Appendix lists the relative Bouguer and residual gravity anomaly for the stations of this profile (see Figure I for profile location). 
Comparison of this profile to the residual gravity map of the Hanford reservation ${ }^{1}$ shows only partial agreement (see Plate 1). This profile is perpendicular to an anticlinal structure in the basalt. Deju and Richard ${ }^{1}$ show the structure as a major anticline that is to the south of Gable Mountain and Gable Butte. This profile shows the structure as a double anticline with a minor syncline between. Gable Mountain projects into the northern anticline and the southern anticline is at the same position as the one shown by Deju and Richard. ${ }^{1}$ Plate 1 shows the magnitude of the anomaly. This profile demonstrates that the gravity does relate to the surface expressions of the basalt, but that there is a buried, more dominant structure to the south of Gable Mountain.

\section{YAKIMA BARRICADE PROFILE}

Table 4 in the Appendix lists the relative Bouguer and residual gravity anomaly for the stations of this profile (see Figure I for profile location). Though this profile was a reconnaissance study with significant errors in individual station values caused by errors in horizontal positioning and elevation errors, it shows significant results (see plate 1 ). The profile has a 3.6-milligal anomaly with a \pm .4 -milligal error per station reading. The low is at the site of the cold Creek synclinal axis. The residual gravity map of the Hanford reservation ${ }^{1}$ shows a 3- to 6-milligal low that delineates the cold Creek synclinal structure. This profile continues this low into cold creek valley where it is confined between umtanum and Yakima ridges.

\section{AREA PROFILE}

Table 5 in the Appendix lists the values of the relative Bouguer and residual gravity anomaly for the stations of this profile (see Figure 1 for profile location). This profile, like the Yakima Barricade Profile, had significant horizontal position and elevation errors--producing an

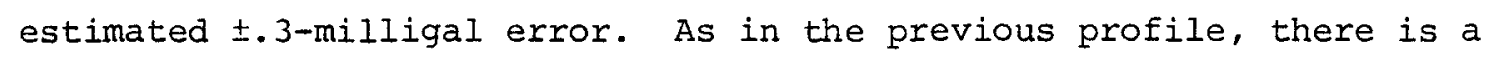
significant gravity low that coincides with the position of the axis of the cold creek syncline on the residual gravity map of the Hanford reservation $^{1}$ (see Plate 1 ). 
TWO-DIMENS IONAL GRAVITY MODEL RESULTS

The above profiles were modeled using the Talwani ${ }^{5}$ original computer program for two-dimensional gravity models. This program computes the gravity effects of each $\mathrm{N}$-sided vertical polygon in the model on specific field points. It then plots the gravity profile that would exist if the geology is as described in the model. For the model to be correct, the following conditions must be satisfied:

1. The actual body causing the anomaly must be long enough relative to its width to be considered infinite in the long dimension;

2. The body must be totally below or above the elevation of the gravity station;

3. Either the density, contrast of the material within the polygon to the surrounding material, or the shape of the polygon must be known. Conditions 1 and 2 are reasonably well satisfied, but the error in these conditions cannot be quantitatively established. Condition 3 is not well satisfied. In most cases, well data are far enough from the specific profile to be of little value and density estimates of the material covering the basalt surface are subject to significant, but unknown, error. Because of the unknowns listed above, the models shown in Figure 2 must be considered valid only if the following assumptions are valid: 1. The water table during the gravity measurements was as shown in the December 1975 water table map of the Hanford reservation; ${ }^{6}$

2. The density of unsaturated glaciofluviatile material is 1.7 grams per cubic centimeter;

3. The density of water-saturated materials above the basalt is 0.65 gram per cubic centimeter lower than the basalt density;

4. The basalt surface is predictable and can be projected from known well sites to the profiles.

As all these conditions cannot be proven valid for any profile, the profiles must be considered as one of several possible causes of the gravity variations. Figure 2 shows the geologic profiles that the author believes exist based on the above assumptions. 


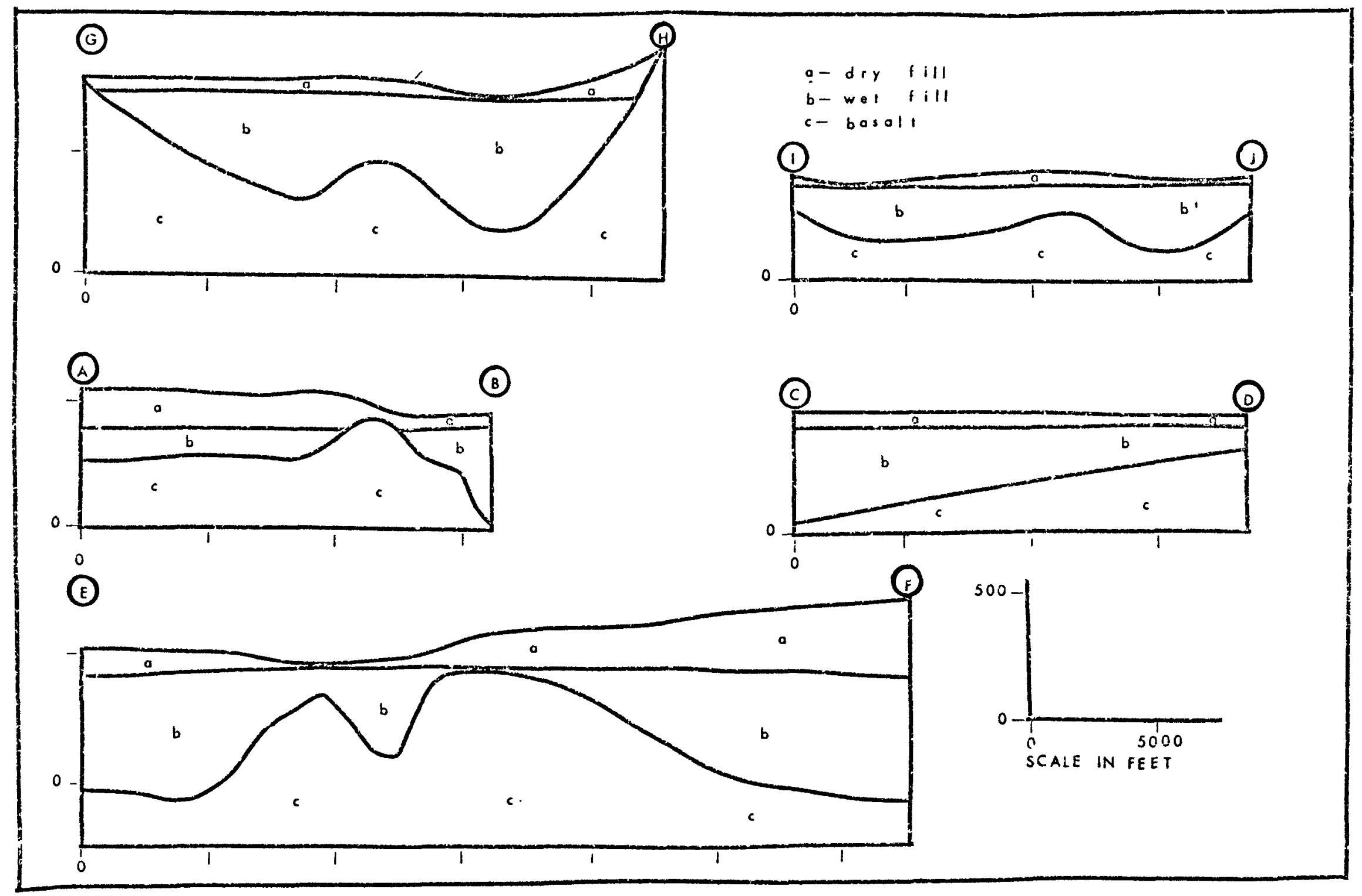

\section{FIGURE 2}

TWO-DIMENSIONAL GRAVITY MODELS OF THE PROFILE SHOWN ON FIGURE 1

$A-B=$ GABLE MOUNTAIN, $C-D=$ GABLE BUTTE, E-F = NORTH-SOUTH GABLE MOUNTAIN-GABLE BUTTE, $\mathrm{G}-\mathrm{H}=$ YAKIMA BARRICADE, I-J $=300$ AREA 
CONCLUSIONS

This study has verified the existence of gravity lows at selected sites in the Hanford reservation. The lows are considered to mainly reflect differences in the depth to the basalt surface. These lows probably were sites of ancestral river systems. As such, they would be filled with coarse, better sorted materials than the average basin fill and, therefore, be sites of highly permeable deposits. Figure 3 shows two ancestral river valleys suggested by this study. The northern one may have been an ancestral Columbia channel, whereas the southern one may have been an ancestral Yakima channel. The locations of these channels appear to be supported also by the residual gravity map of the Hanford reservation ${ }^{1}$ and the bedrock contour map of the Hanford reservation by summers and Deju. 7

The gravity data and surface geology suggest that the channel going between Gable Mountain and Gable Butte may have flowed through a synclinal trough, then cut south across a presently buried anticlinal structure into the cold Creek syncline. Geologic data in Cold Creek Valley indicate that the Yakima River probably occupied this valley in the past. If so, it would have followed the cold Creek syncline as shown in Figure 3.

REFERENCES

1. R. A. Deju and B. H. Richard, A Regional Gravity Investigation of the Hanford Reservation, ARH-C-8, for Atlantic Richfield Hanford Company, Richland, Washington (1975).

2. D. E. Peterson, Variations in the Earth's Gravity Field at Hanford, BNWL-235, 3, Battelle, Pacific Northwest Laboratories, Richland, Washington (1965).

3. D. E. Peterson, Bouguer Gravity Anomalies on the Hanford Reservation, BNWL-481, 3, Battelle, Pacific Northwest Laboratories, Richland, Washington (1966).

4. M. B. Dobrin, Introduction to Geophysical Prospecting, McGraw-Hill, New York, New York, 466 pp. (1960). 


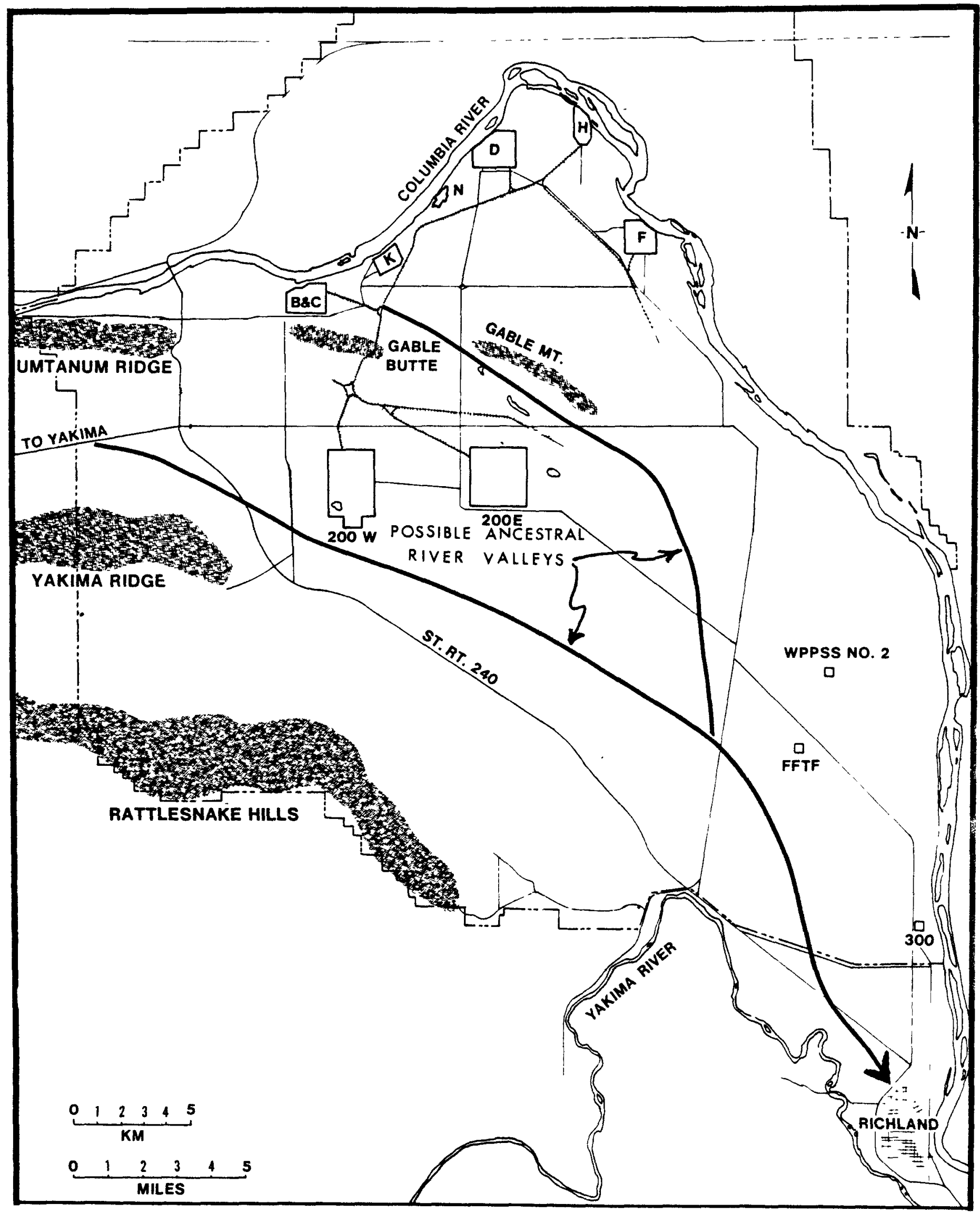

FIGURE 3

LOCATION OF POSSIBLE BURIED RIVER CHANNELS SUGGESTED BY

THE GRAVITY PROFILES SHOWN IN FIGURE 1 AND THE RESIDUAL GRAVITY MAP OF THE HANFORD RESERVATION ${ }^{1}$ 
5. M. Talwani, J. L. Worzel, and M. M. Landis, "Gravity Computation for Two-Dimensional Bodies with Application to the Mendocino Submarine Fracture Zone," Journal of Geophysical Research (1959).

6. Hanford Reservation Water Table Map, Atlantic Richfield Hanford Company, Richland, Washington (1975).

7. W. K. Summers and R. A. Deju, A Preliminary Review of the Regional Hydrology of the Hanford Reservation, $A R H-C-5$ and RAD-4, for Atlantic Richfield Hanford Company, Richland, Washington (1974).

DISTRIBUTION

Number of

Copies

8

ATLANTIC RICHFIELD HANFORD COMPANY

D. J. Brown

R. A. Deju

R. E. Gephart

R. E. Isaacson

Document Control (4)

11

OTHERS

J. T. Lillie

B. H. Richard (10) 
ARH-C-23

BHR-1

APPENDIX 
TABLE 1

GABLE MOUNTAIN GRAVITY PROFILE DATA

\begin{tabular}{|c|c|c|c|c|}
\hline $\begin{array}{l}\text { Distance East } \\
\text { of A, Profile } \\
\text { A-B, Figure } 1 \\
\text { (in feet) }\end{array}$ & $\begin{array}{l}\text { Elevation } \\
\text { (in feet) }\end{array}$ & $\begin{array}{l}\text { Relative } \\
\text { Bouguer } \\
\text { Gravity } \\
\text { Anomaly } \\
\text { (in mgal) }\end{array}$ & $\begin{array}{l}\text { Regional } \\
\text { Gravity } \\
\text { Correction } \\
\text { (in mgal) }\end{array}$ & $\begin{array}{l}\text { Residual } \\
\text { Gravity } \\
\text { Anomaly } \\
\text { (in mgal) }\end{array}$ \\
\hline $\begin{array}{l}0 \\
200 \\
400 \\
600 \\
800 \\
1000 \\
1200 \\
1400 \\
1600 \\
1800 \\
2000 \\
2200 \\
2400 \\
2600 \\
2800 \\
3000 \\
3200 \\
3400 \\
3600 \\
3800 \\
4000 \\
4200 \\
4400 \\
4600 \\
4800 \\
5000 \\
5200 \\
5400 \\
5600 \\
5800 \\
6000 \\
6200 \\
6400 \\
6600 \\
6800 \\
7000 \\
7200 \\
7400 \\
7600 \\
7800 \\
8000 \\
8200 \\
8400 \\
8600 \\
8800 \\
9000 \\
9200 \\
9400\end{array}$ & $\begin{array}{l}561.21 \\
561.23 \\
561.22 \\
558.82 \\
554.26 \\
549.99 \\
548.21 \\
548.37 \\
548.74 \\
549.11 \\
549.73 \\
550.19 \\
550.79 \\
551.81 \\
552.52 \\
553.44 \\
554.25 \\
555.03 \\
555.21 \\
555.65 \\
556.01 \\
556.57 \\
556.57 \\
554.48 \\
549.43 \\
542.44 \\
537.40 \\
535.73 \\
535.58 \\
536.14 \\
536.20 \\
536.84 \\
537.74 \\
539.18 \\
540.65 \\
542.02 \\
543.49 \\
544.75 \\
545.24 \\
547.64 \\
548.45 \\
548.52 \\
548.77 \\
548.77 \\
548.59 \\
549.03 \\
549.17 \\
550.52\end{array}$ & $\begin{array}{l}8.06 \\
7.98 \\
7.97 \\
7.80 \\
7.86 \\
7.93 \\
7.95 \\
8.00 \\
7.96 \\
8.02 \\
8.06 \\
8.09 \\
8.13 \\
8.21 \\
8.26 \\
8.33 \\
8.39 \\
8.51 \\
8.52 \\
8.55 \\
8.51 \\
8.64 \\
8.61 \\
8.62 \\
8.62 \\
8.58 \\
8.73 \\
8.61 \\
8.65 \\
8.74 \\
8.70 \\
8.68 \\
8.70 \\
8.73 \\
8.71 \\
8.77 \\
8.83 \\
8.80 \\
8.76 \\
8.79 \\
8.68 \\
8.70 \\
8.62 \\
8.60 \\
8.66 \\
8.76 \\
8.81 \\
8.99\end{array}$ & $\begin{array}{l}0 \\
+.01 \\
+.02 \\
+.03 \\
+.04 \\
+.05 \\
+.06 \\
+.07 \\
+.07 \\
+.08 \\
+.09 \\
+.10 \\
+.10 \\
+.11 \\
+.12 \\
+.13 \\
+.14 \\
+.14 \\
+.13 \\
+.16 \\
+.17 \\
+.17 \\
+.18 \\
+.19 \\
+.20 \\
+.20 \\
+.21 \\
+.22 \\
+.22 \\
+.23 \\
+.24 \\
+.25 \\
+.25 \\
+.26 \\
+.27 \\
+.28 \\
+.29 \\
+.29 \\
+.30 \\
+.31 \\
+.31 \\
+.32 \\
+.33 \\
+.34 \\
+.35 \\
+.36 \\
+.36 \\
+.37\end{array}$ & $\begin{array}{l}8.06 \\
7.99 \\
7.99 \\
7.83 \\
7.90 \\
7.98 \\
8.01 \\
8.07 \\
8.03 \\
8.10 \\
8.15 \\
8.19 \\
8.23 \\
8.32 \\
8.38 \\
8.46 \\
8.53 \\
8.66 \\
8.67 \\
8.71 \\
8.68 \\
8.81 \\
8.79 \\
8.80 \\
8.82 \\
8.78 \\
8.94 \\
8.83 \\
8.87 \\
8.97 \\
8.94 \\
8.93 \\
8.95 \\
8.99 \\
8.98 \\
9.05 \\
9.12 \\
9.09 \\
9.06 \\
9.09 \\
8.99 \\
9.02 \\
8.95 \\
8.94 \\
9.01 \\
9.12 \\
9.17 \\
9.46\end{array}$ \\
\hline
\end{tabular}


Table I (continued)

\begin{tabular}{|c|c|c|c|c|}
\hline $\begin{array}{l}\text { Distance East } \\
\text { of A, Profile } \\
\text { A-B, Figure I } \\
\text { (in feet) }\end{array}$ & $\begin{array}{l}\text { Elevation } \\
\text { (in feet) }\end{array}$ & $\begin{array}{l}\text { Relative } \\
\text { Bouguer } \\
\text { Gravity } \\
\text { Anomaly } \\
\text { (in mgal) }\end{array}$ & $\begin{array}{l}\text { Regional } \\
\text { Gravity } \\
\text { Correction } \\
\text { (in mgal) }\end{array}$ & $\begin{array}{l}\text { Pesidual } \\
\text { Gravity } \\
\text { Anomaly } \\
\text { (in mgal) }\end{array}$ \\
\hline $\begin{array}{r}9600 \\
9800 \\
10000 \\
10200 \\
10400 \\
10600 \\
10800 \\
11000 \\
11200 \\
11400 \\
11600 \\
11800 \\
12000 \\
12200 \\
12400 \\
12600 \\
12800 \\
13000 \\
13200 \\
13400 \\
13600 \\
13800 \\
14000 \\
14200 \\
14400 \\
14600 \\
14800 \\
15000 \\
15200 \\
15400 \\
15600 \\
15800\end{array}$ & $\begin{array}{l}547.82 \\
547.66 \\
547.52 \\
547.50 \\
547.71 \\
547.90 \\
537.14 \\
516.88 \\
504.15 \\
495.95 \\
486.84 \\
476.87 \\
470.77 \\
465.22 \\
464.55 \\
464.67 \\
464.12 \\
463.75 \\
454.18 \\
454.04 \\
455.05 \\
456.49 \\
458.00 \\
459.09 \\
460.68 \\
462.30 \\
463.70 \\
465.20 \\
456.66 \\
461.38 \\
458.86 \\
460.86\end{array}$ & $\begin{array}{l}8.93 \\
8.90 \\
8.77 \\
8.70 \\
8.73 \\
9.37 \\
9.78 \\
9.66 \\
9.55 \\
9.57 \\
9.89 \\
9.73 \\
9.49 \\
9.02 \\
8.81 \\
8.72 \\
8.67 \\
8.63 \\
8.02 \\
7.92 \\
7.92 \\
7.94 \\
7.92 \\
7.97 \\
7.83 \\
7.77 \\
7.65 \\
7.73 \\
6.99 \\
7.20 \\
6.90 \\
6.95\end{array}$ & $\begin{array}{l}+.37 \\
+.38 \\
+.39 \\
+.40 \\
+.40 \\
+.41 \\
+.41 \\
+.42 \\
+.42 \\
+.43 \\
+.44 \\
+.45 \\
+.46 \\
+.47 \\
+.43 \\
+.49 \\
+.49 \\
+.50 \\
+.52 \\
+.54 \\
+.57 \\
+.59 \\
+.62 \\
+.64 \\
+.67 \\
+.70 \\
+.72 \\
+.74 \\
+.77 \\
+.80 \\
+.82 \\
+.85\end{array}$ & $\begin{array}{r}9.30 \\
9.28 \\
9.16 \\
9.10 \\
9.13 \\
9.78 \\
10.19 \\
10.18 \\
9.97 \\
10.00 \\
10.33 \\
10.18 \\
9.95 \\
9.49 \\
9.29 \\
9.21 \\
9.16 \\
9.13 \\
8.54 \\
8.46 \\
8.49 \\
8.53 \\
8.54 \\
8.61 \\
8.50 \\
8.47 \\
8.37 \\
8.47 \\
7.76 \\
8.00 \\
7.72 \\
7.80\end{array}$ \\
\hline
\end{tabular}


TABLE 2

GABLE BUTTE GRAVITY PROFILE DATA

\begin{tabular}{|c|c|c|c|c|}
\hline $\begin{array}{l}\text { Distance East } \\
\text { of C, Profile } \\
\text { C-D, Figure I } \\
\text { (in feet) }\end{array}$ & $\begin{array}{l}\text { Elevation } \\
\text { (in feet) }\end{array}$ & $\begin{array}{l}\text { Relative } \\
\text { Bouguer } \\
\text { Gravity } \\
\text { Anomaly } \\
\text { (in mgal) }\end{array}$ & $\begin{array}{l}\text { Eegional } \\
\text { Gravity } \\
\text { Correction } \\
\text { (in mgal) }\end{array}$ & $\begin{array}{l}\text { Residual } \\
\text { Gravity } \\
\text { Anomaly } \\
\text { (in mgal) }\end{array}$ \\
\hline $\begin{array}{r}0 \\
200 \\
400 \\
600 \\
800 \\
1000 \\
1200 \\
1400 \\
1600 \\
1800 \\
2000 \\
2200 \\
2400 \\
2600 \\
2800 \\
3000 \\
3200 \\
3400 \\
3600 \\
3800 \\
4000 \\
4200 \\
4400 \\
4600 \\
4800 \\
5000 \\
5200 \\
5400 \\
5600 \\
5800 \\
6000 \\
6200 \\
6400 \\
6600 \\
6800 \\
7000 \\
7200 \\
7400 \\
7600 \\
7800 \\
8000 \\
8200 \\
8400 \\
8600 \\
8800 \\
9000 \\
9200 \\
9400 \\
9600\end{array}$ & $\begin{array}{l}741.85 \\
738.09 \\
734.09 \\
729.61 \\
725.54 \\
722.82 \\
720.30 \\
717.52 \\
714.69 \\
712.33 \\
708.62 \\
703.68 \\
698.18 \\
693.82 \\
691.35 \\
689.90 \\
688.32 \\
687.06 \\
685.86 \\
684.35 \\
683.93 \\
682.48 \\
681.20 \\
679.84 \\
678.33 \\
677.08 \\
675.66 \\
674.01 \\
670.85 \\
666.37 \\
663.20 \\
661.96 \\
661.60 \\
660.67 \\
659.87 \\
659.28 \\
658.88 \\
658.23 \\
658.25 \\
659.41 \\
657.33 \\
656.06 \\
654.51 \\
653.27 \\
652.35 \\
652.77 \\
653.35 \\
654.07 \\
654.93\end{array}$ & $\begin{array}{l}5.69 \\
5.77 \\
5.79 \\
5.78 \\
5.78 \\
5.85 \\
5.79 \\
5.92 \\
5.92 \\
5.96 \\
6.01 \\
6.10 \\
6.04 \\
6.10 \\
6.09 \\
6.14 \\
6.15 \\
6.16 \\
6.15 \\
6.13 \\
6.33 \\
6.35 \\
6.39 \\
6.40 \\
6.42 \\
6.48 \\
6.53 \\
6.56 \\
6.60 \\
6.71 \\
6.75 \\
6.75 \\
6.81 \\
6.85 \\
6.76 \\
6.82 \\
6.89 \\
6.94 \\
7.01 \\
7.06 \\
7.03 \\
7.10 \\
7.10 \\
7.25 \\
7.30 \\
7.35 \\
7.40 \\
7.45 \\
7.56\end{array}$ & $\begin{array}{l}+.90 \\
+.88 \\
+.86 \\
+.83 \\
+.81 \\
+.78 \\
+.76 \\
+.74 \\
+.71 \\
+.68 \\
+.66 \\
+.63 \\
+.60 \\
+.60 \\
+.59 \\
+.58 \\
+.58 \\
+.57 \\
+.56 \\
+.55 \\
+.54 \\
+.53 \\
+.52 \\
+.51 \\
+.50 \\
+.49 \\
+.48 \\
+.47 \\
+.46 \\
+.45 \\
+.45 \\
+.44 \\
+.43 \\
+.42 \\
+.41 \\
+.40 \\
+.39 \\
+.38 \\
+.37 \\
+.36 \\
+.35 \\
+.34 \\
+.33 \\
+.32 \\
+.31 \\
+.30 \\
+.29 \\
+.28 \\
+.27\end{array}$ & $\begin{array}{l}6.59 \\
6.65 \\
6.65 \\
6.61 \\
6.59 \\
6.63 \\
6.55 \\
6.66 \\
6.63 \\
6.64 \\
6.65 \\
6.73 \\
6.64 \\
6.70 \\
6.68 \\
6.72 \\
6.73 \\
6.72 \\
6.71 \\
6.68 \\
6.87 \\
6.88 \\
6.91 \\
6.91 \\
6.91 \\
6.97 \\
7.01 \\
7.01 \\
7.06 \\
7.16 \\
7.20 \\
7.19 \\
7.24 \\
7.27 \\
7.17 \\
7.18 \\
7.28 \\
7.32 \\
7.38 \\
7.42 \\
7.38 \\
7.44 \\
7.43 \\
7.57 \\
7.61 \\
7.65 \\
7.69 \\
7.73 \\
7.83\end{array}$ \\
\hline
\end{tabular}


Table 2 (continued)

\begin{tabular}{|c|c|c|c|c|}
\hline $\begin{array}{l}\text { Distance East } \\
\text { of C, Profile } \\
\text { C-D, Figure } 1 \\
\text { (in feet) }\end{array}$ & $\begin{array}{l}\text { Elevation } \\
\text { (in feet) }\end{array}$ & $\begin{array}{l}\text { Reiative } \\
\text { Bouguer } \\
\text { Gravity } \\
\text { Anomaly } \\
\text { (in mgal) }\end{array}$ & $\begin{array}{l}\text { Kegional } \\
\text { Gravity } \\
\text { Correction } \\
\text { (in mgal) }\end{array}$ & $\begin{array}{l}\text { Residual } \\
\text { Gravity } \\
\text { Anomaly } \\
\text { (in mgal) }\end{array}$ \\
\hline $\begin{array}{r}9800 \\
10000 \\
10200 \\
10400 \\
10600 \\
10800 \\
11000 \\
11200 \\
11400 \\
11600 \\
11800 \\
12000 \\
12200 \\
12400 \\
12600 \\
12800 \\
13000 \\
13200 \\
13400 \\
13600 \\
13800 \\
14000 \\
14200 \\
14400 \\
14600 \\
14800 \\
15000 \\
15200 \\
15400 \\
15600 \\
15800\end{array}$ & $\begin{array}{l}655.28 \\
654.37 \\
653.59 \\
653.12 \\
652.38 \\
652.53 \\
650.78 \\
650.06 \\
649.33 \\
648.88 \\
648.86 \\
648.78 \\
648.84 \\
648.76 \\
648.24 \\
647.42 \\
646.54 \\
646.16 \\
645.65 \\
645.14 \\
644.50 \\
643.72 \\
643.32 \\
642.00 \\
641.74 \\
641.22 \\
640.08 \\
639.08 \\
638.88 \\
638.05 \\
636.64\end{array}$ & $\begin{array}{l}7.61 \\
7.63 \\
7.65 \\
7.68 \\
7.71 \\
7.81 \\
7.74 \\
7.73 \\
7.65 \\
7.70 \\
7.60 \\
7.64 \\
7.72 \\
7.84 \\
7.99 \\
8.07 \\
8.07 \\
8.12 \\
8.15 \\
8.16 \\
8.19 \\
8.21 \\
8.26 \\
8.29 \\
8.24 \\
8.21 \\
8.33 \\
8.20 \\
8.39 \\
8.44 \\
8.42\end{array}$ & $\begin{array}{l}+.26 \\
+.26 \\
+.25 \\
+.24 \\
+.23 \\
+.22 \\
+.21 \\
+.20 \\
+.20 \\
+.19 \\
+.18 \\
+.17 \\
+.17 \\
+.16 \\
+.15 \\
+.14 \\
+.13 \\
+.12 \\
+.11 \\
+.10 \\
+.09 \\
+.08 \\
+.07 \\
+.06 \\
+.05 \\
+.04 \\
+.03 \\
+.02 \\
+.01 \\
+0 \\
0\end{array}$ & $\begin{array}{l}7.87 \\
7.89 \\
7.90 \\
7.91 \\
7.94 \\
8.03 \\
7.95 \\
7.93 \\
7.85 \\
7.89 \\
7.78 \\
7.81 \\
7.89 \\
8.00 \\
8.14 \\
8.21 \\
8.20 \\
8.24 \\
8.26 \\
8.26 \\
8.28 \\
8.29 \\
8.33 \\
8.35 \\
8.29 \\
8.25 \\
8.36 \\
8.22 \\
8.40 \\
8.44 \\
8.42\end{array}$ \\
\hline
\end{tabular}


TABLE 3

NORTH-SOUTH GABLE MOUNTAIN-GABLE BUTTE GRAVITY PROFILE DATA

\begin{tabular}{|c|c|c|c|c|}
\hline $\begin{array}{l}\text { Distance South } \\
\text { of E, Profile } \\
\text { E-E, Figure I } \\
\text { (in feet) }\end{array}$ & $\begin{array}{l}\text { E.levation } \\
\text { (in feet) }\end{array}$ & $\begin{array}{l}\text { Eelative } \\
\text { Bouguer } \\
\text { Gravity } \\
\text { Anomaly } \\
\text { (in mgal) }\end{array}$ & $\begin{array}{l}\text { Regional } \\
\text { Gravity } \\
\text { Correction } \\
\text { (in mgal) }\end{array}$ & $\begin{array}{l}\text { Fesidual } \\
\text { Gravity } \\
\text { Anomaly } \\
\text { (in mgal) }\end{array}$ \\
\hline $\begin{array}{r}0 \\
300 \\
600 \\
900 \\
1200 \\
1500 \\
1800 \\
2100 \\
2400 \\
2700 \\
3000 \\
3300 \\
3600 \\
3900 \\
4200 \\
4500 \\
4800 \\
5100 \\
5400 \\
5700 \\
6000 \\
6300 \\
6600 \\
6900 \\
7200 \\
7500 \\
7800 \\
8100 \\
8400 \\
8700 \\
9000 \\
9300 \\
9600 \\
9900 \\
10200 \\
10500 \\
10800 \\
11100 \\
11400 \\
11700 \\
12000 \\
12300 \\
12600 \\
12900 \\
13200 \\
13500 \\
13800 \\
14100 \\
14400 \\
14700 \\
15000 \\
15300\end{array}$ & $\begin{array}{l}533.46 \\
534.73 \\
535.26 \\
536.09 \\
536.52 \\
535.98 \\
537.19 \\
536.40 \\
535.45 \\
534.54 \\
533.93 \\
532.92 \\
532.04 \\
531.16 \\
529.43 \\
523.94 \\
515.34 \\
503.80 \\
496.93 \\
494.65 \\
494.05 \\
493.69 \\
492.84 \\
492.30 \\
491.85 \\
490.88 \\
490.44 \\
489.99 \\
489.13 \\
486.77 \\
485.93 \\
484.34 \\
482.88 \\
481.54 \\
481.78 \\
434.14 \\
486.89 \\
489.97 \\
492.36 \\
493.97 \\
493.85 \\
493.67 \\
503.74 \\
519.19 \\
534.96 \\
546.82 \\
555.25 \\
564.72 \\
566.39 \\
567.46 \\
568.35 \\
569.15\end{array}$ & $\begin{array}{l}4.99 \\
4.95 \\
4.91 \\
4.86 \\
4.73 \\
4.77 \\
4.65 \\
4.63 \\
4.73 \\
4.59 \\
4.51 \\
4.45 \\
4.45 \\
4.44 \\
4.44 \\
4.36 \\
4.38 \\
4.44 \\
4.53 \\
4.56 \\
4.62 \\
4.90 \\
5.17 \\
5.60 \\
6.44 \\
7.31 \\
7.75 \\
8.07 \\
8.25 \\
8.04 \\
8.17 \\
8.14 \\
8.20 \\
8.22 \\
8.33 \\
8.33 \\
8.14 \\
8.05 \\
7.86 \\
7.77 \\
7.54 \\
7.38 \\
7.26 \\
7.31 \\
7.46 \\
7.65 \\
7.99 \\
8.52 \\
8.53 \\
8.77 \\
9.03 \\
9.11\end{array}$ & $\begin{array}{l}+.55 \\
+.54 \\
+.54 \\
+.53 \\
+.52 \\
+.51 \\
+.50 \\
+.49 \\
+.49 \\
+.48 \\
+.48 \\
+.46 \\
+.45 \\
+.44 \\
+.44 \\
+.43 \\
+.42 \\
+.41 \\
+.40 \\
+.39 \\
+.39 \\
+.38 \\
+.37 \\
+.36 \\
+.35 \\
+.34 \\
+.34 \\
+.33 \\
+.33 \\
+.31 \\
+.30 \\
+.29 \\
+.29 \\
+.28 \\
+.27 \\
+.26 \\
+.25 \\
+.25 \\
+.24 \\
+.23 \\
+.22 \\
+.21 \\
+.20 \\
+.20 \\
+.19 \\
+.18 \\
+.17 \\
+.16 \\
+.116 \\
+.15 \\
+.13\end{array}$ & $\begin{array}{l}5.54 \\
5.49 \\
5.45 \\
5.39 \\
5.25 \\
5.28 \\
5.15 \\
5.12 \\
5.22 \\
5.07 \\
4.98 \\
4.91 \\
4.90 \\
4.88 \\
4.88 \\
4.79 \\
4.80 \\
4.85 \\
4.93 \\
4.95 \\
5.01 \\
5.28 \\
5.54 \\
5.96 \\
6.79 \\
7.65 \\
8.09 \\
8.40 \\
8.57 \\
8.35 \\
8.47 \\
8.37 \\
8.49 \\
8.50 \\
8.60 \\
8.59 \\
8.39 \\
8.30 \\
8.10 \\
8.00 \\
7.76 \\
7.59 \\
7.46 \\
7.51 \\
7.65 \\
7.83 \\
8.16 \\
8.68 \\
8.69 \\
8.92 \\
9.17 \\
9.24\end{array}$ \\
\hline
\end{tabular}


Table 3 (continued)

\begin{tabular}{|c|c|c|c|c|}
\hline $\begin{array}{l}\text { Distance South } \\
\text { of E, Profile } \\
\text { E-F, Figure } 1 \\
\text { (in feet) }\end{array}$ & $\begin{array}{l}\text { Elevation } \\
\text { (in feet) }\end{array}$ & $\begin{array}{l}\text { Eelative } \\
\text { Bouguer } \\
\text { Gravity } \\
\text { Anomaly } \\
\text { (in mgal) }\end{array}$ & $\begin{array}{l}\text { Regional } \\
\text { Gravity } \\
\text { Correction } \\
\text { (in mgal) }\end{array}$ & $\begin{array}{l}\text { iesudual } \\
\text { Gravity } \\
\text { Anomaly } \\
\text { (in mgal) }\end{array}$ \\
\hline 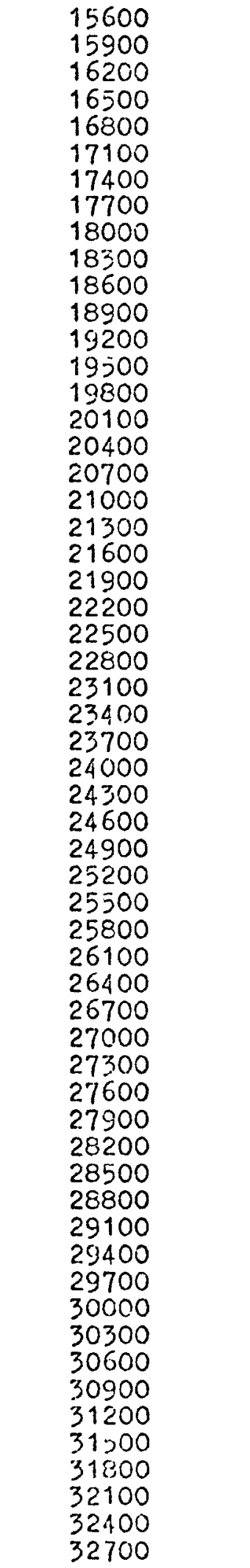 & $\begin{array}{l}570.06 \\
571.04 \\
571.81 \\
572.83 \\
573.69 \\
573.38 \\
572.34 \\
570.62 \\
568.30 \\
566.24 \\
565.78 \\
561.94 \\
559.68 \\
560.02 \\
561.16 \\
562.76 \\
564.32 \\
565.77 \\
567.39 \\
572.37 \\
584.87 \\
599.47 \\
602.14 \\
610.72 \\
618.52 \\
626.11 \\
634.67 \\
643.96 \\
652.48 \\
659.88 \\
666.78 \\
672.74 \\
678.62 \\
683.76 \\
689.54 \\
694.79 \\
698.41 \\
701.35 \\
704.24 \\
706.36 \\
707.05 \\
708.15 \\
711.16 \\
712.69 \\
715.04 \\
716.42 \\
716.76 \\
717.44 \\
717.30 \\
718.63 \\
723.82 \\
728.25 \\
725.76 \\
717.183 \\
708.81 \\
708.58 \\
716.56 \\
727.93\end{array}$ & $\begin{array}{l}9.19 \\
9.18 \\
9.19 \\
9.10 \\
9.17 \\
9.12 \\
9.07 \\
9.05 \\
9.01 \\
8.97 \\
8.86 \\
8.72 \\
8.77 \\
8.69 \\
8.72 \\
8.64 \\
8.71 \\
8.61 \\
8.58 \\
8.54 \\
8.35 \\
8.31 \\
7.59 \\
7.70 \\
7.76 \\
7.60 \\
7.55 \\
7.63 \\
7.51 \\
7.41 \\
7.39 \\
7.29 \\
7.25 \\
7.25 \\
7.22 \\
7.19 \\
7.13 \\
7.09 \\
6.92 \\
6.81 \\
6.76 \\
6.62 \\
6.62 \\
6.47 \\
6.27 \\
6.24 \\
6.22 \\
6.17 \\
6.05 \\
6.06 \\
5.99 \\
5.91 \\
5.85 \\
5.73 \\
5.69 \\
5.65 \\
5.41 \\
5.57\end{array}$ & $\begin{array}{l}+.12 \\
+.11 \\
+.11 \\
+.10 \\
+.09 \\
+.08 \\
+.07 \\
+.06 \\
+.06 \\
+.05 \\
+.04 \\
+.03 \\
+.02 \\
+.02 \\
+.01 \\
-.01 \\
-.02 \\
-.03 \\
-.03 \\
-.03 \\
-.04 \\
-.05 \\
-.05 \\
-.06 \\
-.07 \\
-.08 \\
-.09 \\
-.10 \\
-.10 \\
-.11 \\
-.12 \\
-.13 \\
-.14 \\
-.15 \\
-.15 \\
-.16 \\
-.17 \\
-.18 \\
-.19 \\
-.20 \\
-.21 \\
-.21 \\
-.22 \\
-.23 \\
-.24 \\
-. .25 \\
-.26 \\
-.26 \\
-.27 \\
-.28 \\
-. .29 \\
-.30 \\
-. .31 \\
-. .31 \\
-.32 \\
-.33 \\
-.34\end{array}$ & $\begin{array}{l}9.31 \\
9.29 \\
9.30 \\
9.20 \\
9.26 \\
9.20 \\
9.14 \\
9.11 \\
9.07 \\
9.02 \\
8.90 \\
8.75 \\
8.79 \\
8.71 \\
8.73 \\
8.64 \\
8.70 \\
8.59 \\
8.55 \\
8.51 \\
8.32 \\
8.27 \\
7.52 \\
7.65 \\
7.70 \\
7.53 \\
7.47 \\
7.54 \\
7.42 \\
7.31 \\
7.28 \\
7.17 \\
7.12 \\
7.11 \\
7.07 \\
7.04 \\
6.97 \\
6.92 \\
6.74 \\
6.62 \\
6.56 \\
6.41 \\
6.41 \\
6.25 \\
6.04 \\
6.00 \\
5.97 \\
5.91 \\
5.79 \\
5.79 \\
5.71 \\
5.62 \\
5.55 \\
5.42 \\
5.38 \\
5.33 \\
5.08 \\
5.23\end{array}$ \\
\hline
\end{tabular}


TABLE 4

YAKIMA BARRICADE GRAVITY PROFILE DATA

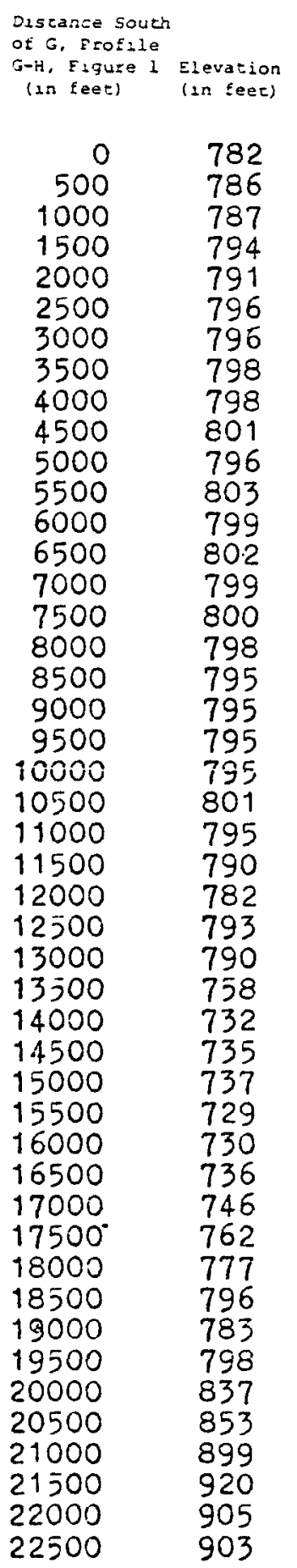

\begin{tabular}{|c|c|c|c|c|}
\hline $\begin{array}{l}\text { Relative } \\
\text { Bouquez } \\
\text { Gravitiy } \\
\text { Anomaly } \\
\text { (1n mgal) }\end{array}$ & $\begin{array}{l}\text { Topogzaphic } \\
\text { Curreztion } \\
\text { (2.: mgal) }\end{array}$ & $\begin{array}{l}\text { Topocrapnically } \\
\text { Corrected } \\
\text { Bouguer } \\
\text { Anomaly } \\
\text { (1n mgal) }\end{array}$ & $\begin{array}{l}\text { Regional } \\
\text { Graviey } \\
\text { Correction } \\
\text { (2n mgal) }\end{array}$ & $\begin{array}{l}\text { Residual } \\
\text { Gravizy } \\
\text { Anomaly } \\
\text { (in mgal) }\end{array}$ \\
\hline $\begin{array}{l}5.96 \\
5.76 \\
5.38 \\
5.81 \\
5.34 \\
5.73 \\
5.74 \\
5.53 \\
5.35 \\
5.47 \\
5.05 \\
5.44 \\
5.00 \\
5.02 \\
4.61 \\
4.32 \\
4.29 \\
4.50 \\
3.96 \\
4.26 \\
4.56 \\
4.14 \\
4.22 \\
5.39 \\
5.06 \\
5.30 \\
4.94 \\
4.91 \\
4.62 \\
4.60 \\
4.61 \\
3.77 \\
3.85 \\
4.20 \\
4.85 \\
4.96 \\
4.86 \\
4.33 \\
5.66 \\
4.88 \\
6.10 \\
5.83 \\
7.31 \\
7.99 \\
7.42 \\
8.71\end{array}$ & $\begin{array}{l}.14 \\
.14 \\
.15 \\
.16 \\
.17 \\
.18 \\
.19 \\
.20 \\
.21 \\
.22 \\
.23 \\
.24 \\
.25 \\
.26 \\
.27 \\
.28 \\
.29 \\
.30 \\
.31 \\
.32 \\
.33 \\
.34 \\
.35 \\
.36 \\
.37 \\
.38 \\
.39 \\
.40 \\
.40 \\
.40 \\
.40 \\
.40 \\
.40 \\
.40 \\
.41 \\
.41 \\
.41 \\
.41 \\
.42 \\
.43 \\
.44 \\
.45 \\
.46 \\
.47 \\
.48 \\
.49\end{array}$ & $\begin{array}{l}6.10 \\
5.90 \\
5.53 \\
5.97 \\
5.41 \\
5.91 \\
5.93 \\
5.73 \\
5.36 \\
5.69 \\
5.28 \\
5.68 \\
5.25 \\
5.28 \\
4.88 \\
4.60 \\
4.58 \\
4.80 \\
4.27 \\
4.58 \\
4.89 \\
4.48 \\
4.57 \\
5.75 \\
5.43 \\
5.68 \\
5.39 \\
5.31 \\
5.02 \\
5.00 \\
5.01 \\
4.17 \\
4.25 \\
4.60 \\
5.26 \\
5.37 \\
5.27 \\
4.94 \\
6.08 \\
5.31 \\
6.54 \\
6.28 \\
7.77 \\
8.46 \\
7.90 \\
9.20\end{array}$ & $\begin{array}{l}-3.00 \\
-3.07 \\
-3.13 \\
-3.00 \\
-3.27 \\
-3.33 \\
-3.40 \\
-3.47 \\
-3.53 \\
-3.60 \\
-3.67 \\
-3.73 \\
-3.80 \\
-3.87 \\
-3.93 \\
-4.00 \\
-4.07 \\
-4.13 \\
-4.20 \\
-4.27 \\
-4.33 \\
-4.40 \\
-4.47 \\
-4.53 \\
-4.60 \\
-4.67 \\
-4.73 \\
-4.80 \\
-4.87 \\
-4.93 \\
-5.00 \\
-5.07 \\
-5.13 \\
-5.20 \\
-5.27 \\
-5.33 \\
-5.40 \\
-5.47 \\
-5.53 \\
-5.60 \\
-5.67 \\
-5.73 \\
-5.80 \\
-5.87 \\
-5.93 \\
-5.00\end{array}$ & $\begin{array}{l}3.10 \\
2.83 \\
2.40 \\
2.77 \\
2.14 \\
2.58 \\
2.33 \\
2.26 \\
2.03 \\
2.09 \\
1.61 \\
1.95 \\
1.45 \\
1.41 \\
.95 \\
.60 \\
.51 \\
.67 \\
.07 \\
.31 \\
.56 \\
.08 \\
.10 \\
1.22 \\
.83 \\
1.01 \\
.66 \\
.51 \\
.25 \\
.07 \\
.01 \\
-.09 \\
-.88 \\
-.60 \\
-.01 \\
-.04 \\
-.13 \\
-.53 \\
.055 \\
-.29 \\
.87 \\
.55 \\
1.97 \\
2.59 \\
1.97 \\
3.20\end{array}$ \\
\hline
\end{tabular}


TABLE 5

300 AREA GRAVITY PROFILE DATA

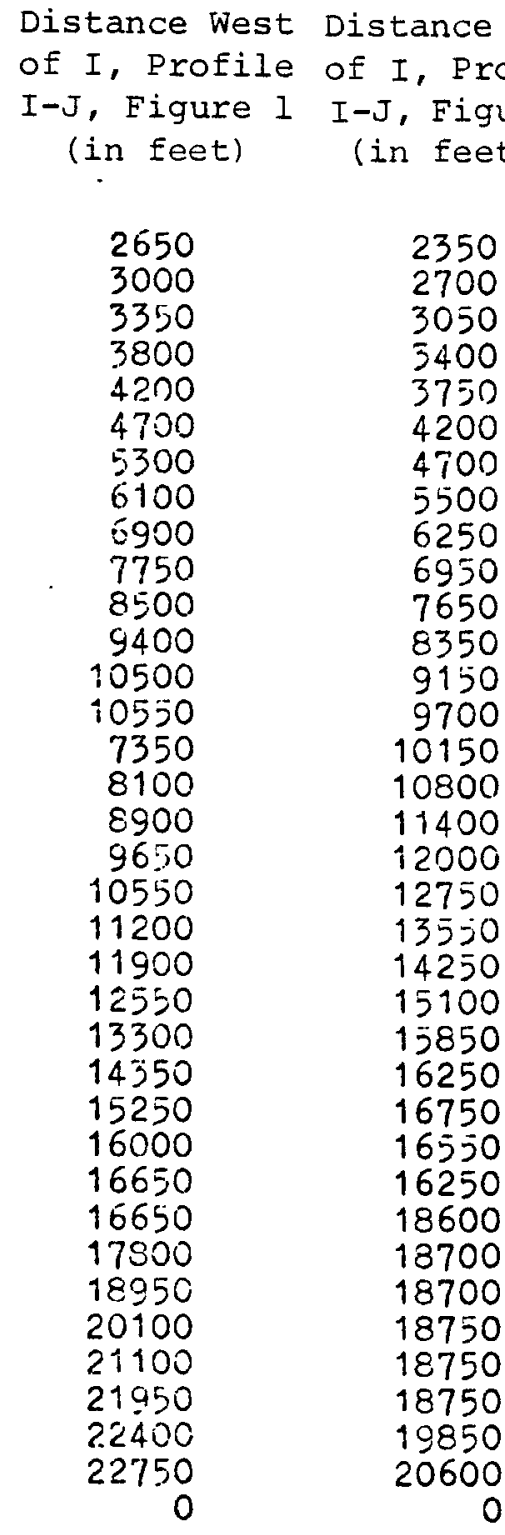

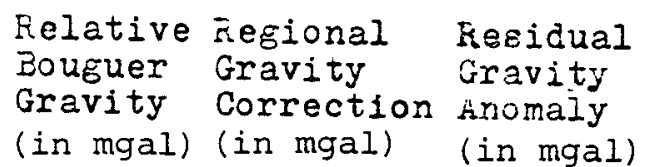

Elevation

(in mgal) (in mgal)

(in mgal)

\begin{tabular}{|c|c|}
\hline $\begin{array}{l}-4.13 \\
-4.13 \\
-4.83 \\
-4.20 \\
-3.95 \\
-3.72 \\
-3.12 \\
-3.15 \\
-3.28 \\
-3.47 \\
-3.18 \\
-3.13 \\
-2.96 \\
-3.20 \\
-3.81 \\
-3.62 \\
-3.26 \\
-3.40 \\
-3.06 \\
-2.79 \\
-2.27 \\
-3.24 \\
-1.99 \\
-2.32 \\
-1.73 \\
-1.88 \\
-1.71 \\
-0.92 \\
-1.09 \\
.0 .86 \\
1.12 \\
0.40 \\
0.23 \\
0.67 \\
0.52 \\
4.09\end{array}$ & $\begin{array}{l}-0.59 \\
-0.68 \\
-0.77 \\
-0.86 \\
-0.93 \\
-1.13 \\
-1.32 \\
-1.53 \\
-1.73 \\
-1.91 \\
-2.09 \\
-2.27 \\
-2.36 \\
-2.50 \\
-1.77 \\
-1.87 \\
-2.40 \\
-2.60 \\
-2.91 \\
-3.09 \\
-3.20 \\
-3.34 \\
-3.48 \\
-3.62 \\
-3.76 \\
-3.90 \\
-4.00 \\
-4.00 \\
-4.10 \\
-4.20 \\
-4.30 \\
-4.40 \\
-4.50 \\
-4.65 \\
-4.75 \\
\end{array}$ \\
\hline
\end{tabular}


